\title{
The Effect of the Intravenous Infusion of Lactate and Phosphate Solutions on Urinary Excretion of Minerals and Hydroxyproline in Sheep
}

\author{
Yoshiaki Terashima, Nobuhito Tohrai and Hiroshi IToH \\ Department of Animal Science, Kitasato University, \\ Towada-shi 034
}

(Received October 7, 1977)

\begin{abstract}
Changes in serum mineral ( $\mathrm{Ca}$, inorganic $\mathrm{P}$ and $\mathrm{Mg}$ ) level and urinary excretion of minerals and hydroxyproline (Hyp) by the intravenous infusion of physiological saline, $0.2 \mathrm{M}$ lactate $(\mathrm{pH} \mathrm{7.5})$ and lactate + phosphate $(\mathrm{pH} 5.0,6.2 \mathrm{gP} / 500 \mathrm{ml})$ solutions at a rate of $500 \mathrm{~m} l$ daily for 3 days were determined in sheep fed orchardgrass hay. The serum lactic acid increased about 1.5 times after the infusion of either lactate or lactate +phosphate solution compared to that of the saline infusion. Serum mineral levels were unaffected by the infusion of lactate and the increased inorganic $\mathrm{P}$ and the decreased $\mathrm{Ca}$ concentrations were observed by the addition of phosphate. The urinary excretion of $\mathrm{P}$ was significantly increased by the lactate infusion and the small decreased urinary excretion of $\mathrm{Ca}$ occurred after the treatment. These trends were emphasized by the infusion of lactate + phosphate solution. Urinary excretion of Hyp was significantly increased by the infusion of lactate solution and was apt to decrease after infusion of lactate + phosphate solution. It seems that the increased $\mathrm{P}$ excretion is induced by the increase of bone resorption due to a concomitant of the increased blood lactate, and the increment of blood phosphorus depresses the bone resorption increased by the infusion of lactate and also brings the decreased calcium excretion.
\end{abstract}

In our previous experiment ${ }^{1}$, it was observed that the urinary excretion of calcium and phosphorus was increased by the intravenous infusion of lactic acid in sheep fed roughage. On the other hand, when sheep were fed the concentrate, the urinary excretion of phosphorus markedly increased and calcium excretion showed less change compared to that in animals fed roughage ${ }^{2)}$. From such observations the question arised whether the increase in urinary phosphous excretion in sheep fed concentrate is due to the acidification (acidosis) of body fluid induced by the increase of acid production in the rumen or due to the other factors associated with concentrate feeding. Yano et al. ${ }^{3)}$ observed a high correlation between the rumen lactic acid concentration and the urinary phosphorus excretion in sheep which have no obvious symptoms of acidosis. MoRITA et al. ${ }^{4)}$ observed the increased urinary excretion of phosphorus after the intravenous injection of sodium lactate. It is assumed, therefore, that some different mechanisms from the acidification of body fluid would be also involved in the increase of phosphorus excretion.

The increase of serum phosphorus concentration has been observed in sheep fed concentrate compared to that of sheep fed roughage ${ }^{2)}$. It has been known that phosphorus metabolism in the ruminant considerably changes in relation to the amount of saliva secretion ${ }^{5,6)}$. Since the secretion of saliva decreases in ruminants fed concentrate usually containing abundant phosphorus? ${ }^{7)}$, Jap. J. Zootech. Sci., 49, (3): 189-194. 
the blood concentration of phosphorus would be increased in such animals. It seems, therefore, that the increase of the blood concentrations of both phosphorus and lactic acid would affect the mineral metabolism of ruminants fed concentrate. Urinary mineral excretion in sheep has been known to change in relation to bone metabolism ${ }^{8)}$ and urinary hydroxyproline excretion will furnish an index of turnover of bone matrix ${ }^{9}$. However, there are few reports investigated the effect of the abundant supply of phosphorus and the infusion of lactic acid on the mineral metabolism in ruminants.

The present experiment was conducted to know the effects of the intravenous infusion of either lactate or lactate + phosphate solution on urinary excretion of minerals and hydroxyproline.

\section{Meterials and Methods}

The experiment was performed on three wethers weighing about $49 \mathrm{~kg}$ each. They. were housed in a individual metabolic cage and $1 \mathrm{~kg}$ orchardgrass hay. per day was given in two equal portions at 9:00 and 16:00. This hay contained $3.7 \mathrm{~g}$ calcium, $3.1 \mathrm{~g}$ phosphorus and $2.3 \mathrm{~g}$ magnesium per kg. Water was freely avaiable. At the beginning of the infusion experiment polyethylene catheter was introduced into the jugular vein. The solutions used for infusion were physiological saline, $0.2 \mathrm{M}$ lactate and $0.2 \mathrm{M}$ lactate+phosphate solution, and these solutions were infused continuously for 3 days at a rate of $500 \mathrm{~m} l /$ day through the catheter by the speed controlled injector. These infusion treatments were conducted according to a latin square design with more than two weeks intervals without treatment. The lactate solution was prepared by adjusting $0.2 \mathrm{M}$ DL-lactic acid solution at $\mathrm{pH} 7.5$ with sodium hydroxide solution. The lactate+ phosphate solution contained $27.2 \mathrm{~g}$ of $\mathrm{KH}_{2} \mathrm{PO}_{4}$ in $500 \mathrm{ml}$ of $0.2 \mathrm{M}$ lactate solution and it supplied $6.2 \mathrm{~g}$ phosphorus, about two times as much as the daily phosphorus intake.

Blood samples were obtained from the opposite site of jugular vein for infusion just before the feeding at 9:00 and urine was collected for every $24 \mathrm{hrs}$ during the experiment period. Analytical method of lactic acid, calcium and magnesium was described in recent reports ${ }^{1,8)}$. Phosphorus was determined by the method of DRYER ${ }^{10}$. Hydroxyproline (Hyp) content of urine was determined by the method of KIVIRIKKo et al. ${ }^{11)}$

\section{Results}

Blood and urine $\mathrm{pH}$ and serum concentrations of lactic acid and minerals in sheep received each treatment are shown in Table 1. Blood and urine $\mathrm{pH}$ of animals infused with the lactate so-

Table 1. Effect of each infusion on blood and uriae $\mathrm{pH}$ and serum concentration of lactic acid and minerals in sheep. ( $\mathrm{mg} / 100 \mathrm{ml}$ )

$(\mathrm{M} \pm \mathrm{SE}, \mathrm{n}=9)$

\begin{tabular}{lccc}
\hline \multicolumn{1}{c}{ Infusion } & $\begin{array}{c}\text { Physiological } \\
\text { saline }\end{array}$ & Lactate $^{1}$ & $\begin{array}{c}\text { Lactate }+. \\
\text { Phosphate }^{2}\end{array}$ \\
\hline Blood pH & $7.46 \pm 0.04$ & $7.52 \pm 0.03$ & $7.47 \pm 0.03$ \\
Urine pH & $8.24 \pm 0.14$ & $8.50 \pm 0.09$ & $8.05 \pm 0.17$ \\
Lactic acid & $11.4 \pm 0.6$ & $14.8 \pm 0.8^{* *}$ & $14.8 \pm 0.9 *$ \\
Calcium & $10.0 \pm 0.2$ & $9.7 \pm 0.3$ & $8.2 \pm 0.9 * *$ \\
Inorganic phosphate & $6.3 \pm 0.2$ & $5.6 \pm 0.4$ & $11.6 \pm 0.9 * *$ \\
Magnesium & $2.4 \pm 0.0$ & $2.2 \pm 0.3$ & $2.3 \pm 0.1$ \\
\hline
\end{tabular}

*) $\mathrm{P}<0.05, * *) \mathrm{P}<0.01$. Significantly different from physiological saline at each level. 1) $0.2 \mathrm{M}$ lactate solution ( $\mathrm{pH} 7.5$, adjusted by sodium hydroxide solution) 2) $\mathrm{KH}_{2} \mathrm{PO}_{4} 54.4 \mathrm{~g} / 1000 \mathrm{~m} l 0.2 \mathrm{M}$ lactate solution ( $\mathrm{pH} 5.0$ ). 


\section{Urinary Mineral Excretion and Lactate Infusion}

lulion was slightly higher than that in the other treatments without statistical significance. The serum lactic acid levels in sheep infused with either the lactate or the lactate + phosphate solution were significantly higher than that of the physiological saline group.

Serum $\mathrm{Ca}$ concentration was not changed with the lactate infusion and it was decreased significantly by the addition of phosphate to the lactate solution. The infusion of lactate + phosphate solution significantly increased serum inorganic $P$ concentration to about 2 times as much as that observed with the infusion of other solutions. There were no differences in serum $\mathrm{Mg}$ levels among the treatments.

Daily changes in urinary excretion of $\mathrm{Ca}, \mathrm{P}, \mathrm{Mg}$ and Hyp are shown in Fig. 1 . In sheep infused with the physiological saline, there were no consistant daily changes on all the estimates.
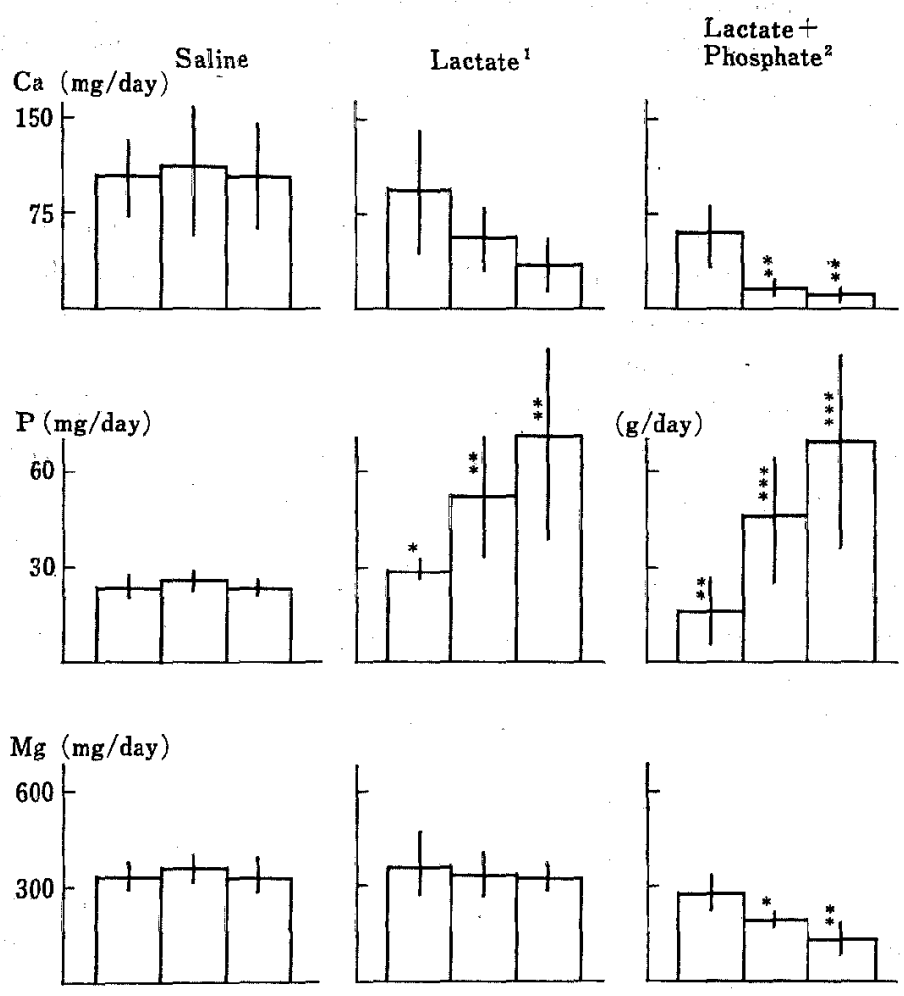

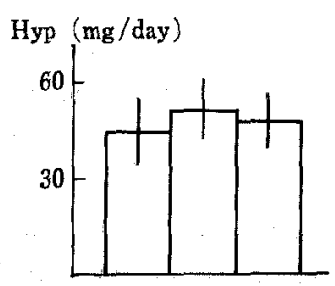

1st 2nd 3rd

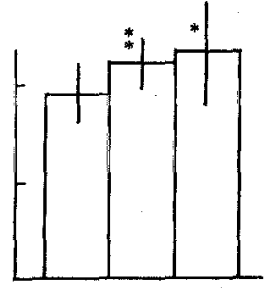

1st 2nd 3rd Day after infusion

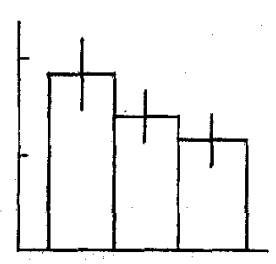

1st 2nd 3rd

Fig. 1. Effect of each infusion on urinary excretion of minerals and hydroxyproline (Hyp) in sheep. Vertical bars represent standard errors of means for three trials. *) $\mathrm{P}<0.10, * *) \mathrm{P}<0.05, * * *) \mathrm{P}<0.01$. Significantly different from physiological saline at each level. 1, 2) See Table 1. 


\section{Terashima, Tohral and ItoH}

On the 2nd and 3rd day of the lactate infusion period, urinary calcium excretion tended to decrease compared to that of the saline infusion but the change was not statistically significant. In contrast, the significant higher excretion of phosphorus was observed during the lactate infusion period and it increased three times as much as that of the saline infusion on the 3rd day of the period. Magnesium excretion showed no appreciable changes. The remarkable decrease of calcium excretion and extreme increase of phosphorus excretion were observed after the infusion of lactate + phosphate solution compared to that of the saline infusion and these changes were statistically significant. Magnesium excretion was lowered significantly by the infusion of lactate+ phosphate solution. Though daily variation of Hyp excretion was considerable low in sheep infused with physiological saline, the infusion of lactate solution significantly increased the urine Hyp excretion. The significant decrease of the urinary Hyp excretion was observed after the infusion of lactate + phosphate solution compared to that of the lactate infusion, but the change did not differ significantly from that of the saline infusion.

\section{Diseussion}

Serum lactic acid concentration was increased to 1.5 times of the control level by the infusion of either lactate or lactate+phosphate solution. It seems likely that since the lactic acid used is a racemic one, the increased lactic acid in blood is mainly occupied by $\mathrm{D}$ form being less metabolized in tissues than $\mathrm{L}$ form ${ }^{12)}$.

The blood and urine $\mathrm{pH}$ of the sheep infused with the lactate solution slightly increased compared to that of the other sheep groups though there were no significant differences. It has been also reported that large persistent increases in arterial $\mathrm{pH}$ and plasma $\mathrm{HCO}_{3}^{-}$occurred after the neutral solution of L-lactate was intravenously injected ${ }^{13}$. It seemed, therefore, that in the sheep infused with the lactate the alkalized body fluid would be induced by the increase of $\mathrm{Na}$ in the blood through the rapid metabolism of lactate when the excess of sodium lactate was intravenously infused to the animals in this experiment.

BoEHNCKE and TIEws ${ }^{21\rangle}$ reported in an experiment of bull calf fed 3 times phosphorus in excess of the requirement for maintainance, the increase of urinary $P$ excretion and decrease of urine $\mathrm{pH}$ occurred. Gold et al. ${ }^{15}$ ) observed the increase of urine $\mathrm{pH}$ in the dog during phosphate depletion. It is assumed, therefore, that the altered acid-base status of body fluid is caused by the changes of the metabolism. The small decrease of urine $\mathrm{pH}$ in sheep infused with the lactate + phosphate solution seemed to result from the low $\mathrm{pH}$ value ( $\mathrm{pH}$ 5.0) of the solution and the excess supply of phosphate.

It has been reported that the marked decrease of $\mathrm{Ca}$ in urine occurred in sheep treated by the injection of sodium lactate, suggesting that it might be induced by alkalized body fluid ${ }^{4)}$ and, that urinary $\mathrm{Ca}$ excretion depends on urine $\mathrm{pH}^{3,16,17)}$. It is assumed, therefore, that the decrease of urine $\mathrm{Ca}$ excretion in sheep infused with the lactate solution is induced by the increase of urine $\mathrm{pH}$ and $\mathrm{P}$ excretion.

MoRITA et al. ${ }^{4)}$ reported that the increase of urine $P$ excretion occurred after the infusion of sodium lactate, suggesting that lactic acid may have another role in changing metabolism of phosphorus other than by acidifying body fluid. However, its mechanism remained obscure.

Since all the Hyp in animal tissues is found in the collagen ${ }^{11}$, the rate of excretion of this compound will furnish an index of turnover of bone matrix. BratThWAITE ${ }^{8)}$ also reported that in sheep receiving the sufficient supply of $P$ there was a close relationship between urine $P$ excretion and bone resorption. It is assumed, therefore, in this experiment that the increase of Hyp 


\section{Urinary Mineral Excretion and Lactate Infusion}

and $P$ in urine is derived from the increase of bone resorption induced by the infusion of lactate solution.

It has been well known that there is a reverse relationship between the $\mathrm{Ca}$ and inorganic $\mathrm{P}$ levels in blood. Some workers ${ }^{18,19)}$ reported that serum $\mathrm{Ca}$ level decreased significantly in animals dosed or infused with the excess phosphorus, and suggested that it was resulted from the increase of bone formation promoted by the increase of blood concentration of phosphorus. Consequently, the decrease of serum $\mathrm{Ca}$ concentration and urine Hyp excretion in sheep infused with the lactate + phosphate solution suggested that the increase of the bone resorption induced by the infusion of lactate would be depressed by the infusion of phosphate.

The depression of urinary excretion of $\mathrm{Ca}$ by the phosphate infusion was more remarkable compared to that of $\mathrm{Mg}$. This result indicates that $\mathrm{Ca}$ excetion is more closely related to $\mathrm{P}$ excretion than that of $\mathrm{Mg}$. Urinary excretion of $\mathrm{P}$ increased gradually with the lapse of time after the phosphate infusion. CiarK et al. ${ }^{20)}$ reported the similar resluts in the sheep treated by the infusion of phosphate. It is suggested, therefore, that phosphate infused intravenously would be circulated via saliva and gradually excreted into feces and urine.

As shown in previous report ${ }^{2}$, urinary excretion of phosphorus in sheep fed the concentrate was higher than that of calcium and this trend was more remarkable compared to that in animals fed the roughage and urinary excretion of these minerals were increased in response to acidosis by the infusion of lactic acid ${ }^{1}$. In this study, however, the increase of urinary $\mathrm{P}$ excretion was observed without the symptoms of acidosis in sheep after lactate infusion.

It is considered from these results that lactic acid which is produced in the rumen of sheep fed concentrate increases the urinary $P$ excretion by stimulating bone resorption and slightly decreases $\mathrm{Ca}$ excretion in urine.

\section{References}

1) Terashima, Y., N. Tohrai and H. Itoh, Jap. J. Zootech. Sci. (submitted)

2) Terashima, Y., I. Shinozaki, N. Tohrai and H. Itoh, Jap. J. Zootech. Sci., 46: 263-268. 1975.

3) Yano, H., K. Mryoshi and R. Kawashima, Jap. J. Zootech. Sci., 47: 270-276. 1976.

4) Morita, T., M. Nokata, H. Yano and R. Kawashima, Jap. J. Zootech. Sci., 48: 8-12. 1977.

5) SATo, H., Jap. J. Vet. Sci., 37: 155-164. 1975.

6) Tomas, F. M., Aust. J. Agric. Res., 25: 495-507. 1974.

7) Tomas, F. M., Aust. J. Agric. Res., 25: 485-493. 1974.

8) Braithwaite, G. D., Brit. J. Nutr., 34: 311-324. 1975.

9) Koevoet, A. L., Clin. Chim. Acta, 12: 232-234. 1965.

10) DrYer, R. L., in Method in Medical Chemistry 3B 1st ed. (S. BABA and K. OKuDA, eds.) 358-359. Nakayama Shoten. Tokyo. 1973.

11) Kivirikko, K. I., O. Laitinen and D. J. Prockop, Anal. Biochem., 19: 249-255. 1967.

12) Hinkson, R. S., W. H. Hoover and E. R. Poulton, J. Anim. Sci., 26: 799-803. 1967.

13) Braide, B. C. and P. H. Dunlop, Am. J. Vet. Res., 30: 1281-1288. 1969.

14) BoennCKe, E. and J. Tiews, Landwirtschaftl. Forschung, 24: 83-90. 1971.

15) Gold, L. W., S. G. Massry, A. I. Arieff and J. W. Coburn, J. Clin. Invest., 52: 2556-2562. 1973.

16) Scott, D., F.G. Whitelaw and M. Kay, Quart. J. Exp. Physiol., 56: 18-32. 1971.

17) Yano, H. and R. Kawashima, Jap. J. Zootech. Sci, 47: 104-109. 1976. 
18) Rasmussen, H. and P. Bordier, The Physiological and Cellular Basis of Metabolic Bone Disease. 1st ed. 170-180. Williams \& Wilkins. Baltimore. 1974.

19) Symonds, H.W. and R.C. Monstrone, Res. Vet. Sci., 16: 131-133. 1974.

20) Clark, R.C., O. E. Budtz-Olsen, R.B. Cross, P. Finnamore and P.A. Baneri, Aust. J. Agric. Res., 24: 913-919. 1973.

\title{
めん羊の尿中無機物および Hydroxyproline 排泄に 対する乳酸塩およびリン酸塩の静脈内投与の影響
}

\author{
寺島福秋・唐来宣人・伊藤宏 \\ 北里大学畜産学部・十和田市 034
}

$\mathrm{pH} 7.5$ に調製した $0.2 \mathrm{M}$ 釈酸液またはこの液にリン 酸塩定添加した溶液 $(12.4 \mathrm{gP} / l)$ を粗飼料給与めえ羊の 静脈内に 1 日当り $500 \mathrm{ml}, 3$ 日間連続投与し，血清無機 物濃度および尿中無機物および Hydroxyproline (Hyp) 排泄量の変化について生理食塩水投与時々比較検討し た. 血清乳酸濃度はこれらの溶液の投与によって約 1.5 店に増加した. 乳酸塩の投与は血清無機物浱度に影響を 与えなかったが，リン酸湓投与時に P 浱度は著しく増加 $し ， \mathrm{Ca}$ 濃度は低下した。乳酸嗑の投与によって尿中 $\mathrm{P}$
および Hyp は有意に增加し，Ca は減少する傾向を示し た. リン酸塩投与時に $\mathrm{P}$ 排泄量は著しく堌加し， Ca お よび Mg 排泄量は減少した. Hyp は乳酸塩投与時に比 較して減少する䝨向を示した．これらの結果より，血中 乳酸の堌加は骨吸収を促進し，尿中P排泄を堌加させる ものと推察された．また血中 $\mathrm{P}$ 濃度の著しい増加は尿中 $\mathrm{P}$ 排泄量定增加させ．Ca排泄量を減少させるものと思 われる。 